Pamiętnik Literacki 2013, 2, s. 107-116
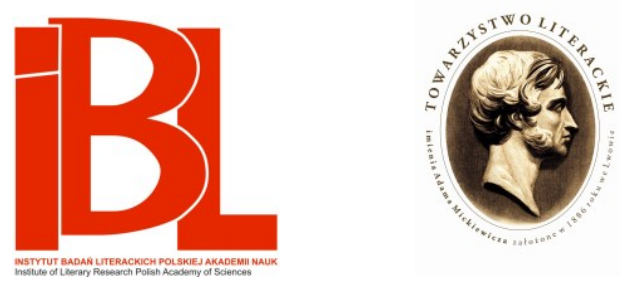

Edelman: opowiadanie, dyskurs świadomości

i konflikt

Zbigniew Kloch 


\section{EDELMAN: OPOWIADANIE, DYSKURS ŚWIADOMOŚCI I KONFLIKT}

Marek Edelman opowiada. Mówiąc, pisząc, udzielając wywiadów, w wystąpieniach z racji rocznic powstań czy innych wydarzeń, w jakich uczestniczył. Opowiadanie jest tu przede wszystkim sposobem porządkowania i przekazywania doświadczenia. Opowiadając można pozostawać w kontakcie z tym, czego już nie ma, co jednak bezsprzecznie się wydarzyło.

W przypadku, o jakim mowa, ,ja” z wypowiedzi może być bez trudu utożsamione z osobowym ,ja" Marka Edelmana, człowieka o znanym życiu i biografii. Opowiadanie o przeszłości budowane jest $\mathrm{z}$ aktów mowy, które układają się w narrację o losie, własnym i cudzym. To także ekspresja świadomości wydarzeń historii, widzianej z perspektywy własnych przeżyć. Utrwalenie graficzne jest tu w zasadzie wtórne wobec oralności. Jedne wypowiedzi mają więcej cech narracji mówionej, zdań parataktycznych, są wyraziście zdialogizowane, inne zaś - mniej. Jeśli nawet nie słychać głosu tego, kto mówi, to jest on zawsze identyfikowalny, a więc słyszalny chociażby w sensie metaforycznym.

Edelman opowiada o przeszłości głównie dlatego, aby świadczyć. Aby wypełniać ramy, ustanawiać obszar pamięci społecznej. Zresztą sam to wielokrotnie podkreślał:

Jestem już ostatni, który znał tych ludzi z imienia i nazwiska, a pewnie nigdy nikt ich już nie wspomni. Trzeba, żeby został po nich jakiś ślad. [s. 163 ${ }^{1}$

Edelman opowiada właściwie stale to samo, gdyż doświadczenia, nawet tak burzliwego życia, jakie mu przypadło w udziale, są w sumie ograniczone. Opowiada, aby zachować pamięć przeszłych wydarzeń, kształtować wartości, o jakich się zapomina. Opowiadanie jest tu podstawową formą podawczą, ale bywa też, że przekaz dotyczący przeszłości przybiera kształt innego gatunku wypowiedzi. Opowiadania Edelmana pełnią funkcje antropologiczne: są przekaźnikiem doświadczenia egzystencjalnego, z wpisanym w wypowiedź, określonym odniesieniem czasowym i tematycznym. Opowieść dotyczy tego, co narrator przeżył osobiście, lub wydarzeń (faktów), co do których jest pewien, że miały miejsce. Albo tych, o których mu mówiono.

Edelman opowiada o historii. Opowiada o życiu, które było jej częścią. Prze-

1 W ten sposób - podając numer stronicy bezpośrednio po cytacie - odsyłam do: M. E d e 1m a n, I była miłość w getcie. Wysłuchała i zapisała P. S a w i c k a. Warszawa 2009. 
cież on sam tę historię współtworzył. Jako jeden z założycieli Żydowskiej Organizacji Bojowej (ŻOB), jeden z przywódców powstania w getcie, jako uczestnik powstania warszawskiego, opozycjonista $z$ lat PRL. Ma o czym mówić. Ale bywa najczęściej pytany ciągle o te same sytuacje i podobnie na zadawane pytania odpowiada, opisując fakty, wydarzenia.

Aby historia istniała w świadomości społecznej, trzeba ją opowiedzieć, a zatem uporządkować zdarzenia w narracji. Ciąg wydarzeń następujących po sobie w pewnych odstępach czasowych przekształcić w wypowiedź, $\mathrm{w}$ narrację prowadzoną z czyjegoś punktu widzenia, która ma swoje przemilczenia, miejsca puste, niedookreślone, pomija sytuacje, o jakich się po prostu mówić nie chce, i to z bardzo różnych powodów. Bywa, że luki i opuszczenia są o wiele bardziej znaczące niż to, o czym się mówi. Tak czy inaczej, do przeszłości nie mamy innego dostępu niż za pomocą języka. Zdarzenia da się opowiadać na wiele sposobów, ale za każdym razem res gestae przekształcana jest w historia rerum gestarum ${ }^{2}$. W ujęciu semiotycznym historia może być opisana jako komunikacja między władzą a różnymi grupami społecznymi, które stanowią jej przedmiot oddziaływania. W doświadczeniu i przekonaniu potocznym przybiera kształt opowieści świadka wydarzeń. Albo jest ich rekonstrukcją dokonaną przez zawodowego historyka, który mówi do współczesnych i do przyszłych pokoleń.

Sytuacja Edelmana okazuje się zasadniczo inna niż sytuacja zawodowego historyka i bohatera-narratora typowych zapisów historii mówionej. Jego opowieść jest, jeśli tak można rzec, silnie nacechowana semiotyką nazwiska. Mówi ktoś, kto przeżył najgorsze, stał się po wojnie autorytetem, a więc osobą, której relacje trudno podważyć lub podważać po prostu nie wypada, gdyż burzyłoby to kulturowy system wartości i obraz przeszłości, nie tak przecież odległej. W swych opowieściach o tym, co było, jest Edelman dość subiektywny. Mówiąc, co ma do powiedzenia, nie stroni od uogólnień, które dotyczą przeszłości i oceny zachowań konkretnych ludzi. Słowa stają się nośnikiem twierdzeń wykraczających poza doświadczenie indywidualne. O zachowaniach ludzi w sytuacjach ekstremalnych, o wartości życia, o świecie w jego konkretnym kształcie.

Wypowiedzi Edelmana są niekiedy pełne zniecierpliwienia, że innym trudno pojąć rzeczy dla niego oczywiste, pełne konfliktów werbalnych, za którymi stoi konflikt świadomości.

Życie codzienne? Czego oczekujecie? Jakieś opowieści o miłości? Uświadomcie sobie, że na przestrzeni, gdzie wcześniej mieszkało około 120000 ludzi, naraz upycha się pół miliona. Że masz 5 deko chleba dziennie, kilogram marmolady miesięcznie i dwa razy w miesiącu po 200 gramów cukru... Jeśli nie masz co jeść, jeśli z głodu puchną ci nogi, to nic więcej z siebie nie wykrzeszesz ${ }^{3}$.

Ujmowane z perspektywy typologii form narracyjnych opowiadania Edelmana wykazują wiele cech gatunkowych autobiografii, która jest zarazem historią oralną. Historia mówiona ma z istoty swej właściwości autobiografii, choć najczęściej niekompletnej. Opowiadający mówi o tym, czego doświadczył, co widział,

2 Nawiązuję tu do ustaleń zawartych w książkach: B. A. U s p i e n s k i, Historia i semiotyka. Przeł., wstęp B. Ż yłk o. Gdańsk 1998. - H. Wh it e, Poetyka pisarstwa historycznego. Red. E. Domańska, M. Wilczyński. Kraków 2000.

3 W. B e r és, K. B u r n etk o, Marek Edelman. Życie. Po prostu. Warszawa 2008, s. 68. 
co go bezpośrednio dotyczyło lub czego był jedynie świadkiem. „Oral history” staje się w ten sposób świadectwem nie tylko losów indywidualnych, lecz i doświadczenia grupowego, pokoleniowego, opowieścią o wydarzeniach widzianych „od wewnątrz”, z perspektywy tych, którzy je przeżyli. Autobiografia zdaje się zmieniać proporcje między tym, co w opowieści indywidualne, a tym, co zbiorowe. „Ja” dominuje tu nad opowieścią o innych, jest jej postacią centralną, nawet wówczas gdy opowiada się o doświadczeniu pokoleniowym. Autobiografia z łatwością przechodzi w historię oralną, ta zaś zwykle zawiera elementy autobiografii. Tym obu formom opowieści o przeszłości przypisuje się status prawdziwości i autentyczności. Obie formy zdają się przeżywać rozkwit w dzisiejszej kulturze.

Znawca problematyki literackich i nieliterackich autobiografii, Phillipe Lejeune, pisał o tym typie wypowiedzi jako trudnym do zdefiniowania. Niejednorodnym, jeśli chodzi o tekstowe wyznaczniki gatunku. Lejeune określa autobiografię jako opowieść prozą, w której „,rzeczywista osoba przedstawia swoje życie”" . W autobiografii mówi się zwykle o własnym doświadczeniu życiowym, o indywidualnym losie, co nie zmienia faktu, że często jest los ten wpleciony w kontekst wydarzeń historycznych, w którym opowiadającemu wypadło żyć. W historię zdarzeniową. Autor autobiografii nie ma zazwyczaj ambicji stworzenia syntezy historycznej. Jeśli umieszcza w niej zdania odnoszące się do prawidłowości rozwoju opisywanych wydarzeń, to mają one raczej postać pospiesznie uogólnionych twierdzeń, powszechnie powtarzanych mniemań lub własnych przekonań obdarzonych „,dużym kwantyfikatorem”, takich np. formuł, jak: „Żydem jest każdy, kogo biją” albo „Komuniści robili to metodycznie”.

Autobiografia jako gatunek wypowiedzi (w Bachtinowskim rozumieniu, nieco zmodyfikowanym przez Annę Wierzbicką ${ }^{5}$ ) ma wiele odmian i może być zrealizowana za pomocą różnych konwencji narracyjnych. Lejeune wymienia konstrukcje narracyjne, w których najczęściej pojawiają się elementy autobiograficzne: pamiętniki, biografię, powieść osobistą, dziennik intymny, autoportret. Widać z tego, że autobiografię łatwiej określić poprzez odniesienie tekstu do celu, jaki ma realizować, niż poprzez identyfikację jej formy podawczej. Z obserwacji badacza wynika, że niezbywalne cechy tego rodzaju wypowiedzi to retrospektywny charakter opowieści oraz możliwość utożsamienia narratora z jej głównym bohaterem. Sądzę, że są to wyznaczniki autobiografii, które mogą być w różnym stopniu zrealizowane w rozmaitych tekstach. Autobiografizm wolno więc uznać za stopniowalną właściwość tekstu. W wypowiedziach autobiograficznych ,ja" autorskie daje się z pewnością identyfikować jako ,ja” konkretnej osoby, jako ,ja” niefikcjonalne. W potocznej świadomości kulturowej autobiografia umieszczana jest po stronie reality, podczas gdy w wielu fragmentach może w istocie należeć do fiction. Muszą być zatem spełnione warunki, które pozwolą traktować ,ja" wypowiadające jako ego konkretnej osoby, przedstawiającej realne życie. To utożsamienie jest zwykle potwierdzone wiedzą pozatekstową. Przebiega więc poza językiem. Wiemy, że istniał

4 Ph. L e j e u n e, Wariacje na temat pewnego paktu. O autobiografii. Przeł. W. G r a j e w s k i [i in]. Red. R. Lubas-Bartoszyńska. Kraków 2001, s. 22. Zob. też Ph. L e j e u n e, Je est un autre. L'autobiographie, de la litterature aux medias. Paris 1980.

5 A. W i e r z b i c k a, Genry mowy. W zb.: Tekst i zdanie. Zbiór studiów. Red. T. Dobrzyńska, E. Janus. Warszawa 1983, s. 131. 
Marek Edelman, a wiemy to, bo znaliśmy go osobiście, ktoś nam o tym powiedział, przeczytaliśmy w książce, w gazecie. „Ja” autobiograficzne ma zatem pewne cechy znaku indeksalnego, który odsyła do realnego świata, do rzeczywistej postaci, jest $\mathrm{z}$ nią w takiej relacji jak nazwisko w stosunku do tego, kto je nosi.

Chcę w ten sposób powiedzieć, że autobiografia jako „genre mowy”, jako konstrukcja wypowiedzeniowa, projektuje taką sytuację komunikacyjną, która sprawia wrażenie, że mamy do czynienia z opowieścią prawdziwą. Autobiografia powinna mówić o tym, co się rzeczywiście zdarzyło, i jest to przekonanie konstytutywne dla pojęcia „,paktu autobiograficznego”, określającego relacje między autorem a czytelnikiem autobiografii, kategorii wprowadzonej i kojarzonej z pracami Lejeune'a. Kiedy zatem traktuję cudzą wypowiedź jako autobiograficzną, przypisuję jej znamiona prawdy lub - prawdziwości. Postępuję jak opowiadający, który przekonuje mnie, że to, co mówi, jest prawdą, choć w istocie nie tyle „mówi prawdę", co utrzymuje, że ,ją mówi" że autobiografia jest wypowiedzią ukierunkowaną na upublicznienie prywatnych doświadczeń, a więc na nadawanie im wartości poprzez fakt rozpowszechnienia tekstu autobiograficznego w kulturze. Życie nieznane przekształca się w życie utrwalone w języku, pomnażając tym samym zasoby tekstów, które pozostać mają w pamięci zbiorowej. To próba wyprowadzenia mojego, ,ja" z anonimowej wspólnoty, nadania mu znaczenia, ocalenia w sensie symbolicznym, a zatem do pewnego stopnia także egzystencjalnym. W dzienniku intymnym, będącym przecież swoistą rozmową z samym sobą, ,ja” wypowiadające ulega rozszczepieniu na ,ja”, które mówi, i to drugie moje ,ja”, do którego mówię. W autobiografii ,ja” nie zwraca się w żadnym wypadku do siebie, lecz zawsze - do innych. To w uproszeniu wprowadzanie mojego ,ja” w sferę publiczną, ze wszystkimi tej decyzji konsekwencjami.

Opowieści Edelmana ześrodkowane są na faktach autobiograficznych, choć jest to tendencja narracji o przeszłości, występująca z różnym nasileniem.

Zanim wybuchła wojna, byłem nikim. Chłopakiem po maturze. Bezczelnym chłopakiem. Niewychowanym. [s. 37]

Dystans wobec przeszłości jest tu wyrazisty. Mówiący charakteryzuje siebie z odległej perspektywy czasowej, z oddalenia, stwarza obraz samego siebie widziany z perspektywy teraźniejszości.

Kiedyś poszła plotka, jak się okazało później, nieprawdziwa, że ktoś, gdzieś jest podejrzany i może sypie. Na wszelki wypadek szefostwo Bundu kazało wtedy zawiesić wszystkie kontakty. A ja właśnie robiłem „Biuletyn”, był prawie gotowy, a że byłem bezczelny, po cichu, w tajemnicy przed nimi go skończyłem. Ale nie miałem jak go rozkolportować, bo i kolportaż był zawieszony. [s. 41]

Tu z kolei sformułowania dotyczące historii wzajemnie się przenikają, współgrają ze sobą. Na relację o faktach nakłada się opowieść o samym sobie jako sprawcy wydarzeń, o osobistych motywacjach działania. Wywód ten jest pełen składników deiktycznych i zaimków osobowych łączących go z czasem, osadzających w przestrzeni, odnoszących to, co się mówi, do sytuacji wypowiadania ${ }^{7}$.

6 L e j e u n e, Wariacje na temat pewnego paktu, s. 22 n.

7 Nawiązuję tu do kategorii récit, discours, historie, wprowadzonych przez E. B e n v e $n$ is t e'a (Problème de linguistique générale. Paris 1966, s. 237-249). 
Nie wiedziałem, co zrobić, ale w końcu wymyśliłem. Postanowiłem zorganizować zabawę - „laba” mówiło się w Bundzie. Kupiłem kiełbasę, pół litra wódki i zaprosiłem Bernarda, Berka i Abraszę. [...] I przy tej wódce powiedziałem im, że mam 500 egzemplarzy „Biuletynu” i dwie łączniczki: Miriam Szyfman, która była szefową wszystkich kolporterek (to jej kiedyś pękły w dorożce majtki wyładowane bibułą), i Zosię (sprawdź, jej nazwisko jest na pomniku zabitych w Zielonce). Powiedziałem, że muszę to rozkolportować, bo cała nasza praca pójdzie na marne, a „Biuletyn” będzie zaraz do wyrzucenia. [s. 42]

W tym z kolei fragmencie relacji Edelmana dominuje ekspresja ,ja” wypowiadającego. Narracja przybiera postać wspomnienia, utrzymanego w stylistyce potocznych opowieści o banalnych doświadczeniach życiowych (,kupiłem kiełbasę, pół litra"). Zdarzenia, które przekształcają osobistą narrację w historię oralną, są w zasadzie nieliczne, lecz to opowieść o historii pozostaje tu podstawowym celem wypowiedzi. Ślady owych zdarzeń można odszukać dziś jeszcze, po wielu latach (,sprawdź, jej nazwisko jest na pomniku zabitych w Zielonce”).

Mówiący opowiada w czasie rzeczywistym o zdarzeniach z przeszłości, których był podmiotem i - w jakiejś części - sprawcą. Znanych jest wiele sposobów tego rodzaju opowiadania i zgodnych z nimi stylów narracji, które pełnią konkretne funkcje społeczne. Autobiografia mieści się wśród narracji z wyraźnie określoną perspektywą czasową ${ }^{8}$. Bywa, że mówiący ma wątpliwości co do faktów z przeszłości (,to, chyba, było wtedy, gdy Niemcy...”). Oczywiście, nie zmienia to jego intencji świadczenia o faktach, o prawdzie. Lejeune podkreśla, że narracja autobiograficzna bywa często konstrukcją pochodną od dialogu, jaki odbywa się między ankieterem (lub dziennikarzem) a respondentem (udzielającym wywiadu) ${ }^{9}$. Opowiadanie autobiograficzne jest mówieniem o życiu, o doświadczeniach, a więc o czymś niemożliwym do zmiany. Do przeszłości nie mamy dostępu innego niż poprzez pamięć i teksty, których dystrybucja w kulturze jest reglamentowana: nie każdemu można to samo opowiedzieć, a poza tym każdy inaczej ocenia relację, którą słyszy. Opowiadanie „z dystansu” obejmuje odległe od współczesności wydarzenia i fakty, musi więc uaktywniać pokłady pamięci długotrwałej. Jest zatem z konieczności rekonstrukcją i reinterpretacją przeszłości (,Zanim wybuchła wojna, byłem nikim"). Opowiadania Edelmana o tym, co przeżył, prowokowane były zazwyczaj pytaniami zadawanymi mu w trakcie rozmowy podczas wywiadu. Ktoś, kto pyta o przeszłość, której sam nie doświadczał, pyta, by tak rzec, z perspektywy innej ,strefy czasowej”, co często pytanego drażni, bulwersuje, złości. W aspekcie gatunkowym narracje Edelmana łączą konwencje opisu i opowiadania, są relacją kogoś, kto nie ma problemów z interpretacją wydarzeń z przeszłości. Wie, jak było, choć nie zawsze rozumie, dlaczego w tamtych sytuacjach zachował się tak, nie zaś inaczej. Powtórzę: ,ja" mówiącego w autobiografii zazwyczaj łatwo zidentyfikować. Ten, kto opowiada, jest konkretną osobą, a wiedza o tym, kim on jest, uprawdopodabnia autobiografię. Taką też rolę odgrywa semiotyka nazwiska. Ale to nie tak, że np. opowieści robotników z Fabryki Samochodów Osobowych na Żeraniu w Warszawie mają mniejszą wartość czy są uważane za mniej prawdziwe niż przekazywane przez Edelmana. I w jednym, i w drugim przypadku opowiadanie stanowi rodzaj świadectwa, swoistą topografię przeszłości. W aspekcie semiolo-

8 Zob. m.in. Praktyki opowiadania. Red. B. Owczarek, Z. Mitosek, W. Grajewski. Kraków 2001.

9 L e j e un e, Je est un autre, s. 277-319. 
gicznym autobiografia jest narracją, w której dominują identyfikowalne nazwy osób, miejsc i zdarzeń, a z punktu widzenia zasad opisywania świata przez język autobiografia upodabnia się do opowieści mitycznej, skoro mit rozumiany być może jako język imion własnych ${ }^{10}$. Jest wypowiedzią podatną na mitologizację. Podobnie jak przeszłość w ogóle - ze względu na luki w pamięci narratora, dystans czasowy między aktem opowiadania a okresem, w którym się opowieść rozgrywa, ze względu na świadome bądź nie do końca uświadamiane przemilczenia i przeinaczenia. Mit i historia dotyczą przecież sfery przedstawiania przeszłości, która od dawna jest ważnym przedmiotem zainteresowania kultury ${ }^{11}$.

Historię oralną od historii zdarzeniowej odróżnia przede wszystkim subiektywność opowiadania. Brak tu wyrazistej interpretacji związków przyczynowo-skutkowych opowiadanych zdarzeń. Klasyczna historia zdarzeniowa ufundowana jest na chronologicznym opisie faktów, na wyjaśnianiu ich przyczyn zgodnie z przyjętą figurą interpretacyjną, co prowadzić ma do ujawnienia mechanizmu rozwoju dziejów. Historyk szuka wytłumaczenia źródeł i powiązań wydarzeń. Świadek historii, który relacjonuje przede wszystkim własne doświadczenia, powtarza w istocie: „tak było, widziałem”. Historyk rekonstruuje i interpretuje fakty, których najczęściej nie doświadczał, jeśli zaś pisze o historii „przeżytej”, obowiązuje go zasada obiektywizmu, spychająca osobowe ,ja” narratora poza opowieść. Historyk ma opisywać i wyjaśniać, thumaczyć. Narrator historii oralnej opowiada najczęściej o tym, czego sam doświadczył. Przedmiotem historii zdarzeniowej są fakty, przedmiotem historii mówionej - przeżycia, ale też plotki, przypuszczenia, przekonania (,Kiedyś poszła plotka...”; „Na wszelki wypadek szefostwo Bundu...”). Depozytariuszem prawdy jest pamięć, ta zaś ujawnia się przecież w uwikłaniu językowym, semiologicznym: „Pamięć nie jest bowiem depozytariuszem faktów, lecz aktywnym procesem nadawania znaczeń" 12 .

Z perspektywy psychologicznej opowiadanie o przeszłości stanowi ekspresję werbalną (lub jej zapis) sposobu rozumienia rzeczywistości, własnych doświadczeń, przeżyć. W tym aspekcie pełni bardzo istotne funkcje poznawcze. Jest „,czytaniem” przeszłości, ale i „zapisem” rozumienia świata. Opowiadanie jako akt językowy, narracyjny i jako akt psychologiczny możliwe jest dzięki uruchomieniu konwencji wypowiedzeniowych i schematów poznawczych, które, wprowadzone w mowę, służą reprezentacji rzeczywistości i zawierają (a również ujawniają) reguły przetwarzania informacji o świecie. Zdarzenia osobiste i wydarzenia historyczne do-

${ }_{10}$ Zob. B. Uspienski, J. Łotman, Mit - imię - kultura. W: U s pien ski, Historia i semiotyka.

${ }_{11}$ Zob. K. H a s tru p, Przedstawianie przeszłości. Uwagi na temat mitu i historii. „Konteksty. Polska Sztuka Ludowa" 1997, nr 1/2.

${ }^{12}$ P. F ili p k o w s k i, Historia mówiona $i$ wojna. Doświadczenie obozu koncentracyjnego w perspektywie narracji biograficznych. Wrocław 2010, s. 29. Warto tu także wspomnieć o dawnych (1967) a istotnych rozważaniach R. Barthes'a o roli języka w zapisie faktów historycznych (Dyskurs historii. Przeł. Z. K lo c h, A. Ry s i e w i c z. „Pamiętnik Literacki” 1984, z. 3). Zob. też liczne prace na temat oral history, m.in.: C. C a u th, Unclaimed Experience. Trauma, Narrative, and History. Baltimore 1996. - V. R. Y o w, Recording Oral History: A Guide for the Humanities and Social Science. Lanham 2005. - The Oral History Reader. Ed. R. P e r k s, A. T h o m s o n. Wyd. 2. New York 2006. 
świadczane są w podobny sposób. Aby stały się trwałym elementem świadomości, a więc pamięci, przekształca sięje w opowieść, w narrację. Opowieść nadaje kształt doświadczeniu. Stwierdza Jerzy Trzebiński:

Opowiadając komuś historię, odwołuję się do mojej refleksji na temat doświadczonej lub doświadczanej właśnie historii. Zdarza się też przekazywanie treści świadomości pojawiających się ,w toku” doświadczania.

\section{I dalej:}

Sądzimy, że ważna część naszego doświadczania ma postać doświadczania określonych historii, sądzimy też, że ważna część naszych refleksji na temat doświadczanego świata ma postać refleksji o historiach, które „nam się wydarzyły” lub „które się dzieją”. To nie refleksja nadaje narracyjny sens naszemu doświadczaniu. [...] Doświadczam historii, gdyż moje rozumienie jest sterowane narracyjnymi regułami interpretacji zdarzeń i własnej roli w tych zdarzeniach ${ }^{13}$.

Nie są to z pewnością pozycje podmiotu mówiącego bezwzględnie wykluczające się, lecz raczej tendencje występujące w większości opowiadań.

Edelman w swych opowieściach jest przede wszystkim uczestnikiem wydarzeń. Bardzo rzadko przyjmuje rolę obserwatora. Jest uczestnikiem, choć nie zawsze do końca świadomym, tego, co się dzieje i co należałoby zrobić. Świadomość działań dokonywanych w przeszłości pojawia się później, wraz z ich opisem, interpretacją - wraz z wprowadzeniem ,historii” w machinę języka. Edelman jest agensem, postacią działającą, tak można określić jego rolę w opowiadaniu o przeszłości i samej przeszłości (uczestnik dwu powstań, opozycjonista, później lekarz, nie stroniący od ryzykownych metod terapii).

Ale o przeszłości można opowiadać także z perspektywy obserwatora, świadka wydarzeń, pozbawionego możliwości działania. I tak się zresztą w wypowiedziach wspomnieniowych historii oralnej mówi dość często:

Kiedyś biegniemy z kamieniami i nagle każą nam się zatrzymać. Po obu stronach ścieżki na takich wysokich, jakby barowych stołkach siedzieli esesmani. Na kolanach trzymali karabiny, a obok każdy z nich miał drąg. Jeśli któryś uznał, że więźniowie za wolno biegną, to tym drągiem walił po głowach, po plecach. Kapo robili to samo ${ }^{14}$.

Dominanta narracyjna jest skorelowana zazwyczaj ze świadomością opowiadającego, z postawą, jaką mógł przyjąć w czasie i sytuacji, o których mówi. Pamięć czasu przeszłego zdaje się zawierać obrazy przeżyć, wraz z rolą, jaką się odgrywało w zdarzeniach, ale widzianą z perspektywy teraźniejszej, z perspektywy sytuacji wypowiadania. Jednak opowieści o doświadczeniu granicznym wpisują się w określone schematy, jak wszystkie inne narracje o świecie.

Każda narracja autobiograficzna przywołuje nie tylko indywidualne doświadczenia jej autora, ale także historie i zdarzenia innych, ważne (dla tej grupy więźniów) wydarzenia z historii obozu albo z historii w ogóle. Tylko rozpoznając te społeczne konteksty i torując sobie

13 J. Tr z e b iń s k i, Narracja jako sposób rozumienia świata. W zb.: Praktyki opowiadania, S. $106,107$.

14 A. J u s z k i e w i c z, wspomnienie o przeżyciach obozowych. Cyt. z: Ocaleni z Mauthausen. Relacje polskich więźniów z obozów nazistowskich systemu Mauthausen-Gusen. Wybór i oprac. K. M a doń - M itzn e r. Warszawa 2010, s. 131. 
drogę w ich gąszczu, można się przybliżyć do indywidualnych doświadczeń. Indywidualnych, przeżytych [...], to nie znaczy „,surowych” - nie mogą być takie, już choćby dlatego, że zostały zakomunikowane, wyrażone w języku ${ }^{15}$.

W autobiograficznej narracji o przeszłości obraz, ,ja” nie zawsze musi stanowić prostą funkcję opisywanych zdarzeń. Bywa, że w dużo większym stopniu jest on zależny od aktualnych przekonań o samym sobie, od tego, jak się postrzega siebie w czasach, o których się opowiada. Przeszłość może być przecież widziana z perspektywy teraźniejszości, co prowadzi do jej różnorodnych interpretacji. Nawet przy zgodności faktów opowiadanych przez rozmaite osoby. Lub braku odniesień potrzebnych do zrozumienia świata, o którym się opowiada. To może spowodować konflikt świadomości, co jasno widać w wywiadach z Edelmanem.

Konflikt świadomości szczególnie wyraźny jest w filmie dołączonym do książki Marek Edelman. Życie. Po prostu, która stanowi w dużym stopniu zapis rozmów z Edelmanem przeprowadzonych przez Witolda Beresia i Krzysztofa Burnetkę. Gdy pada pytanie o wątpliwości, które może mieć człowiek strzelający do innego człowieka, Edelman wyraźnie się irytuje.

- Jest pan dzieciak, co to znaczy? Jak pan strzela, to nie wie pan, do kogo pan strzela. Człowiek strzela, Pan Bóg kule nosi ${ }^{16}$.

Doświadczenie przeżyte trudno przełożyć na słowa. Pytający chce się jak najwięcej dowiedzieć, to zrozumiałe. Ale dostęp do przeszłości jest zapośredniczony przez wypowiedzi, teksty, fakty, ideologie, stereotypowe interpretacje. O przeszłości się opowiada, lecz za wypowiedzią (mową) stoi świadomość czasu i doświadczenia, którą trudno przekazać. Relacjonowana przeszłość jest diametralnie różna od teraźniejszości dostępnej rozmówcom. I autobiografię, i historię mówioną zaliczyłbym zatem do szczególnie konfliktogennych gatunków wypowiadania się o przeszłości. Traktowane jako świadectwo prawdy, w istocie konstruują jej obraz z subiektywnego punktu widzenia. Opowieść o przeszłości zawiera prawdę czyjąś, doświadczaną lub rekonstruowaną. Dialog o czasie przeszłym jest więc niejako z konieczności konfliktowy. Opowiadanie nadaje przy tym sens przeszłości, wypowiedzi i narratorowi: buduje obraz życia człowieka ${ }^{17}$. Nieuchronnie powiązana $\mathrm{z}$ interpretacją faktów narracja o przeszłości odwołuje się, z jednej strony, do formacji dyskursywnych kształtujących konwencje mówienia o historii, biografii, z drugiej zaś - do własnych przekonań na temat sensu doświadczanych zdarzeń i własnych możliwości rozumienia świata. Przywołane tu odniesienia występują w opowieściach Edelmana.

Już jest tam takie zdanie gdzieś: najważniejsze jest życie, a jak jest już życie, to najważniejsza jest wolność. Ale potem oddaje się życie za wolność i wtedy nie wiadomo, co jest najważniejsze. Koniec ${ }^{18}$.

Historia mówiona stanowi konstelację subiektywnych opowieści, które budują obraz przeszłości, zapośredniczony przez doświadczenie indywidualne, tylko pozornie wolny od uzależnień ideologicznych. Nie wszyscy, których wypowiedzi

${ }^{15}$ Filipkowski, op. cit., s. 75.

${ }_{16}$ B e r és, B u r n et k o, op. cit., płyta DVD z zapisem filmu.

${ }^{17}$ Zob. Trzebińs ki, op. cit., s. 111-116.

${ }_{18}$ Marek Edelman: Bóg śpi. Ostatnie rozmowy prowadzą W. B e reś i K. B u rnetko. Warszawa 2010, s. 11. 
konstruują „mapę przeszłości”, mają tego świadomość. Edelman jest z pewnością wśród tych, którzy widzą subiektywność tego, o czym i jak opowiadają.

To, co chcę opowiedzieć, to nie jest prawda historyczna. To jest relacja ze zdarzeń, w których uczestniczyłem, oraz to, co wtedy ze skąpych wiadomości do mnie docierało. [s. 105]

Konflikt świadomości może prowadzić do konfliktu w sferze dyskursów kultury. Jednak nie jest to takiej sytuacji warunek konieczny. Jeśli uznać za poprawne rozróżnienie Jurija Łotmana na ,binarne” i ,ternarne” systemy kultury, to można powiedzieć, iż konflikt w kulturach pierwszego rodzaju prowadzi do destrukcji bądź dekonstrukcji systemu, a w kulturach drugiego rodzaju przebiega ewolucyjnie, wzbogaca s e mi o s ferę ${ }^{19}$. Rola konfliktu w kulturze powinna być zatem opisywana i oceniana w ścisłym związku z jej typem i uwarunkowaniami historycznymi. Tyle że w ujęciu semiologicznym kultura sama w sobie jest konfliktowa. Aby mogła istnieć, muszą się na nią składać różne systemy zbudowane ze znaków ikonicznych i znaków werbalnych. Jest przy tym konstelacją tekstów, którym przypisuje się znaczenia. Kultura nie tworzy jednorodnego systemu porządkującego ją w każdym miejscu w taki sam sposób. Wartości przypisywane tekstom i znakom współzawodniczą o centralne miejsce w systemie. Zdaniem Łotmana, kulturą rządzą sprzeczne tendencje: pierwsza, związana ze wzrostem różnorodności, i druga - łącząca się z dążeniem do ujednolicenia, ze wzrostem jednorodności ${ }^{20}$. Na każdym z możliwych do wyznaczenia poziomów kultury funkcjonują teksty, które współtworzą odmiany dyskursu i wypowiedzi będące elementarnymi nośnikami wartości.

Opowieści o doświadczanej przeszłości realizujące wzorzec autobiografii i historii mówionej w przypadku Edelmana są mówieniem o wartościach indywidualnych podniesionych do rangi wartości kulturowej. W centrum stawia się tu życie, relacje wobec drugiego człowieka. Sadzę, że w istocie nieco podobnie jak u Martina Bubera lub Emmanuela Lévinasa, zastanawiających się nad rolą „,odwróconego" czy nieobecnego Boga w świecie doświadczeń granicznych. Bóg, który śpi, przecież w jakiś sposób istnieje, choć z pewnością nie w taki, w jaki by się chciało, by istniał. Mam na myśli analogię w dążeniu do interpretacji świata, nie zaś lekturowe czy filozoficzne powinowactwo.

Rosnące ostatnio zainteresowanie autobiografią i historią mówioną można potraktować jako przejaw poszukiwania autentycznych wartości kulturowych, których świadectwami są wybory osób, czyjeś życie przeżyte bądź przeżywane. Widziałbym w takich dążeniach przeciwwagę dla tendencji unifikacyjnych dzisiejszej kultury, dla zastępowania świata przez znaki, które traktuje się (w mediach, w kulturze masowej) nie tyle jako nośniki znaczenia, co surogaty rzeczywistości. To proces, który Jean Baudrillard nazywał symulacją ${ }^{21}$. Autobiografia i historia mówiona zmuszają do pomyślenia świata, którego dotyczą, gdyż nie potrafią i nie mogą być jego kopią werbalną, obrazowaną w słowach. Prawdopodobnie dlatego autobiografia i historia mówiona stają się ostatnio ważnym składnikiem aktualnego dyskursu o nieodległej przeszłości.

19 Zob. J. Łot m a n, Kultura i eksplozja. Przeł., wstęp B. Ż y ł k o. Warszawa 1999. Zob. też J. M. Ło tm a n, Semiosfera. Sankt-Pietierburg 2000.

${ }^{20}$ J. Ł o tm a n, Semiotyka filmu. Przeł. J. F a ry n o, T. M i c z k a. Warszawa 1983.

${ }^{21}$ J. B a u drilla rd, Symulakryi symulacja. Przeł. S. K ró la k. Warszawa 2005. ntip:mrcin.org. pl 
Abstract

ZBIGNIEW KLOCH

(University of Warsaw)

\section{EDELMAN: SHORT STORY, CONSCIOUSNESS DISCOURSE AND CONFLICT}

The article is a description of the role of the story in Marek Edelman's accounts about the past time of occupation. In the literary genres typology his statements fringe upon autobiography and oral story, whilst in the perspective of the history of events Edelman in his accounts plays the role of a witness of historical events, a source of knowledge about the past and at the same time its interpreter. This issue differs, among others, the situations of narration on past events in Edelman's stories from those produced by professional historians. The case of Edelman, who his description of events usually develops in the situations of dialogues (interview, public speech) with people who lack such experience, becomes a convenient point for formulating a number of theses about consciousness conflict seen as a mechanism co-creating the discourse of culture. 